\title{
Retraction Note: Fixed point theorems and explicit estimates for convergence rates of continuous time Markov chains
}

Zhenhai Yan ${ }^{1,2}$, Guojun Yan ${ }^{3}$ and Ikudol Miyamoto ${ }^{*}$

The original article can be found online at https://doi.org/10.1186/ s13663-015-0443-x

*Correspondence: miyamoto.math@hotmail.com ${ }^{4}$ Graduate School of Mathematics, Nagoya University, Nagoya, Japan Full list of author information is available at the end of the article

\section{Retraction note}

The Editors-in-Chief have retracted this article [1] because it showed evidence of peer review manipulation. In addition, the identity of the corresponding author could not be verified: Nagoya University have confirmed that Ikudol Miyamato has not been affiliated with their Graduate School of Mathematics.

The authors have not responded to any correspondence regarding this retraction.

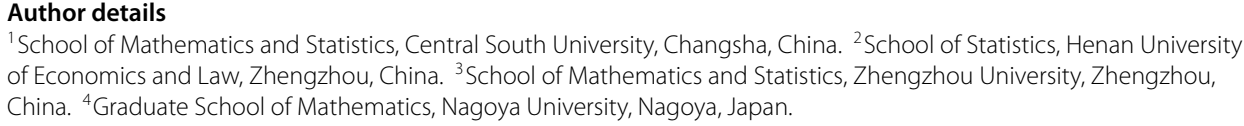

'School of Mathematics and Statistics, Central South University, Changsha, China. ${ }^{2}$ School of Statistics, Henan University of Economics and Law, Zhengzhou, China. ${ }^{3}$ School of Mathematics and Statistics, Zhengzhou University, Zhengzhou, China. ${ }^{4}$ Graduate School of Mathematics, Nagoya University, Nagoya, Japan.

\section{Publisher's Note}

Springer Nature remains neutral with regard to jurisdictional claims in published maps and institutional affiliations.

Published online: 27 February 2020

\section{References}

1. Yan, Z., Yan, G., Miyamoto, I.: Fixed point theorems and explicit estimates for convergence rates of continuous time Markov chains. Fixed Point Theory Appl. 2015, 197 (2015). https://doi.org/10.1186/s13663-015-0443-x

\section{Springer}

(c) The Author(s) 2020. This article is licensed under a Creative Commons Attribution 4.0 International License, which permits use, sharing, adaptation, distribution and reproduction in any medium or format, as long as you give appropriate credit to the original author(s) and the source, provide a link to the Creative Commons licence, and indicate if changes were made. The images or other third party material in this article are included in the article's Creative Commons licence, unless indicated otherwise in a credit line to the material. If material is not included in the article's Creative Commons licence and your intended use is not permitted by statutory regulation or exceeds the permitted use, you will need to obtain permission directly from the copyright holder. To view a copy of this licence, visit http://creativecommons.org/licenses/by/4.0/. 